\title{
The Use of Folk Music in Kindergartens and Family Settings
}

\author{
Olga Denac¹, Jerneja Žnidaršič² \\ ${ }^{1}$ Department of Pre-School Education, University of Maribor, Maribor, Slovenia \\ ${ }^{2}$ Department of Music Education, University of Maribor, Maribor, Slovenia \\ Email: Olga.Denac@um.si
}

How to cite this paper: Denac, O., \& Žnidaršič, J. (2018). The Use of Folk Music in Kindergartens and Family Settings. Creative Education, 9, 2856-2862.

https://doi.org/10.4236/ce.2018.916214

Received: October 26, 2018

Accepted: December 24, 2018

Published: December 27, 2018

Copyright $\odot 2018$ by authors and Scientific Research Publishing Inc. This work is licensed under the Creative Commons Attribution International License (CC BY 4.0).

http://creativecommons.org/licenses/by/4.0/

\begin{abstract}
A relation to singing folk songs, playing folk instruments, and listening to folk music should be developed from a very early stage in a child's development. The objective of our research survey which included teachers and parents of preschool children was to establish how much time families and kindergarten groups dedicate to singing or listening to folk songs and to playing folk instruments and furthermore, what is the level of interest in folk music between preschool children, their parents, and their teachers. Based on our survey results, teachers should dedicate more time to the singing, playing, and listening to folk music, which should be systematically included in the teaching process, while parents should dedicate more time to playing and singing folk music within the family.
\end{abstract}

\section{Keywords}

Folk Music, Music Activities, Preschool Child, Kindergarten, Family

\section{Introduction}

Folk music is an integral part of the culture and lifestyle of each nation. Omerzel Terlep (Omerzel Terlep, 1984) notes that the music that we refer to as folk music is the music of broad masses in a particular time and place, who accept, change, and adapt the creations produced by individuals according to their aesthetic sense (p. 3). Knowing the nation's musical treasure trove is a key prerequisite for the preservation of its folk tradition. The family or parents and grandparents, being a child's first teachers, are a key factor in introducing a child to folk art during pre-school. Kindergartens also play an important role in preserving folk traditions, encouraging, developing, and arousing love of folk music among 
preschool children by way of systematic music education. The integration of activities regarding folk music in kindergartens is connected with facilitation of children's individual development (Fu, 2010) and development of social competences (Zalar, 2015). It is paramount that children are allowed to recognize and experience musical activities (singing, playing, listening, and creating) that are connected and intertwined with folk themes.

According to Zmaga Kumer (Kumer, 2002), folk song is an integral part of Slovenian culture even today, is equal in value to artificial poetry and music and at the same time independent of the two, as it abides by its own rules. A man's first encounter with folk song is one of the earliest experiences a human being can grasp and feel the consequences thereof without fully understanding them.

Children's folk songs should be present in children's lives on a daily basis. Furthermore, Žgavec (2004) strongly recommends, that integration of folk songs is conscious and systematic on all levels of education. Since folk songs are generally short and simple in terms of their text and music, they can be sung by the youngest of children. In that regard, we must be aware about the criteria when we choose the song repertoire. As Borota (2010) states, one needs to consider two fundamental aspects beside the song's artistic merit, namely, their diversity and developmental appropriateness. Naturally, this also means, that we choose a folk song based on its theme, form, language, or rhythmic and melodic structure. According to Kumer (Kumer, 1987), "The content variety of children's songs depends on the environment a child is raised in. The songs of children living in the country reflect the child's contact with nature and animals, while the creativity of urban children is inspired more by the technical sphere. Children's folk songs are frequently merely playful rhyming games or voice imitations. They are also about weather, food, adventures in the pastures or at home; in short, they are about anything that children experience or feel close to" (p. 169). Thus, they can be classified into songs on animals, nature and seasons, songs for playing and amusement, funny songs, counting rhymes, riddle songs, teasing songs, and lullabies.

Playing folk instruments is equally important as folk singing. Along with some of the oldest instruments, such as pan's flute, cross flute, dulcimer, cimbalom, double flute, horns, ocarina, clay pot bass, tambouritsa etc. there are many children's folk instruments and sounders made of different material or common objects, plants, or fruits, such as corn fiddle, rattles, rhythm instruments (pot lids), ratchet, wind rattles, thin paper and a comb, whistles, whit-horns, birch flute, etc. Children's instruments and sound toys in fact include anything that children can use to produce music, sounds, or rhythm; in other words, anything they can blow, clatter, rattle, rub against different surfaces, pluck, strum, or pound (Cvetko, 1991).

One of the main goals of music education in the preschool period is to arouse children's interest in singing folk songs, playing folk instruments, and listening to folk music. However, we need to be conscious of the fact that the attitude to- 
wards music education has changed significantly in recent years. Today it is no longer taken for granted that children are happy to sing, play, and create. The underlying reason for that is the plurality of acoustic stimuli, resulting in passive attitude of children towards musical activities. Children's playful creativity, socialising, or merrymaking is often distracted by television, radio, and computer. In order to preserve our folk tradition through our children and create a positive attitude towards cultural heritage we need a systematic approach to the planning, implementation, and evaluation of music education.

\section{Aims of the Empirical Research}

The survey, which was based on the identified problem, involved preschool teachers and parents of preschool children attending kindergarten. The objective of our study was to identify:

- the position folk music occupies in kindergartens-singing folk songs, playing children's folk instruments, listening to folk songs,

- the level of children's interest in singing folk songs, playing children's folk instruments, and listening to folk songs in kindergarten,

- the position folk music occupies at home-singing folk songs, playing children's folk instruments, and listening to folk songs by both children and their parents.

The study addressed the following research questions:

- How often do preschool teachers incorporate folk music in their education process?

- How many and which children's folk songs did children learn over a period of one year?

- Which music activities related to folk tradition preschool children are happy to take part in?

- How often do children engage in music activities related to folk tradition with their families?

- How often do parents engage in music activities related to folk tradition with their families?

- What significance is attributed to folk music by parents?

Our research sample included preschool teachers $(n=240)$ who teach groups of children of different ages (from 3 to 6 ) and the parents of the children ( $\mathrm{n}=$ 4318). Information was collected using a questionnaire for the teachers and another one for the parents. The data was then processed quantitatively and summarised by means of frequency distribution ( $f, f \%)$.

\section{Results}

\subsection{Research Results Based on the Questionnaire for the Teachers}

How often do preschool teachers incorporate folk music in their education process? 
Most teachers frequently incorporate singing folk songs in the education process, though they rarely play folk instruments or listen to folk music in class. When dealing with folk music, one needs to make sure that all musical activities are equally represented. One of the teacher's tasks is to encourage children to sing folk songs, produce music using folk instruments and sounders, construct simple folk instruments, and actively listen to folk music (Table 1).

How many and which children's folk songs did children learn over a period of one year?

Table 2 clearly shows that on average, preschool children learned 1.7 songs in one year. Preschool teachers should aspire to maintain a certain balance with regard to the number of artificial and folk songs included in the learning process. In other words, they should teach children at least as many folk songs as artificial ones over the period of one year. Judging by the list of song titles, the teachers frequently chose songs that were evidently too difficult in terms of their rhythmic and melodic structure. However, they did make sure that the songs were extremely varied in terms of their content, including songs on animals, nature and seasons, and songs for playing and amusement, as well as, though to a lesser extent, teasing songs, funny songs, and lullabies.

Which music activities related to folk tradition preschool children are happy to take part in?

According to the teachers, most children are often and very often happy to participate in the singing of folk songs, playing folk instruments, and listening to folk music. As children are obviously fond of all music activities, the teachers should include those related to folk themes in the education process more frequently than they presently do. This means that more attention should be paid to playing folk instruments and listening to folk music (Table 3).

Table 1. Frequency of incorporating folk music in the education process.

\begin{tabular}{ccccccc}
\hline \multirow{2}{*}{ Activities } & \multicolumn{2}{c}{ Singing folk songs } & \multicolumn{2}{c}{ Playing folk instruments } & \multicolumn{2}{c}{ Listening to folk music } \\
\cline { 2 - 6 } Answers & $\mathrm{f}$ & $\mathrm{f} \%$ & $\mathrm{f}$ & $\mathrm{f} \%$ & $\mathrm{f}$ & $\mathrm{f} \%$ \\
\hline Very frequently & 22 & 9.2 & 23 & 9.6 & 29 & 12.1 \\
$\begin{array}{c}\text { Frequently } \\
\text { Rarely }\end{array}$ & 133 & 55.4 & 85 & 35.4 & 41 & 17.1 \\
Never & 85 & 35.4 & 88 & 36.7 & 101 & 42.1 \\
Total & 0 & 0 & 44 & 18.3 & 69 & 28.7 \\
\hline
\end{tabular}

Table 2. Number of folk songs learned.

\begin{tabular}{cc} 
Children's age & $3-6$ years \\
Number of songs learned & 401 \\
Number of teachers/units & 240 \\
Average number of songs learned & 1.7 \\
\hline
\end{tabular}


Table 3. Activities children are happy to take part in.

\begin{tabular}{ccccccc}
\hline \multirow{2}{*}{ Activities } & \multicolumn{2}{c}{ Singing folk songs } & \multicolumn{2}{c}{ Playing folk instruments } & \multicolumn{2}{c}{ Listening to folk music } \\
\cline { 2 - 7 } Answers & $\mathrm{f}$ & $\mathrm{f} \%$ & $\mathrm{f}$ & $\mathrm{f} \%$ & $\mathrm{f}$ & $\mathrm{f} \%$ \\
\hline Very frequently & 73 & 30.4 & 103 & 42.9 & 52 & 21.7 \\
Frequently & 124 & 51.7 & 98 & 40.8 & 121 & 50.4 \\
Rarely & 43 & 17.9 & 39 & 16.3 & 67 & 27.9 \\
Never & 0 & 0 & 0 & 0 & 0 & 0 \\
Total & 240 & 100 & 240 & 100 & 240 & 100 \\
\hline
\end{tabular}

\subsection{Research Results Based on the Questionnaire for the Parents}

How often do parents engage in music activities related to folk tradition with their families?

Our results clearly indicate that most parents never listen to folk music, play folk instruments, or actively participate in various folk events. In addition, they rarely sing folk songs at home or attend events with folk themes. Over a half of the interviewed parents rarely acquires sheet music with folk songs. The activities which some of the interviewed parents engage in frequently include singing folk songs and purchasing songbooks with folk music or folk songs (Table 4).

How often do children engage in music activities related to folk tradition with their families?

Based on our survey results we can further conclude that a majority of children never play folk instruments or listen to folk music at home. We can partly attribute that to the inactivity of the parents who do not encourage children to produce or listen to folk music by setting an example and to teachers who rarely incorporate listening to folk music and playing folk instruments in the education process. Children do tend to sing folk songs at home, as this is the one activity that both parents and teachers pay more attention to (Table 5).

What significance is attributed to folk music by parents?

Table 4. Frequency of parents engaging in music activities with their families.

\begin{tabular}{|c|c|c|c|c|c|c|c|c|}
\hline \multirow[b]{2}{*}{ Activities } & \multicolumn{2}{|c|}{ Never } & \multicolumn{2}{|c|}{ Rarely } & \multicolumn{2}{|c|}{ Frequently } & \multicolumn{2}{|c|}{ Total } \\
\hline & $\mathrm{f}$ & $\mathrm{f} \%$ & $\mathrm{f}$ & $\mathrm{f} \%$ & $\mathrm{f}$ & $\mathrm{f} \%$ & $\mathrm{f}$ & $\mathrm{f} \%$ \\
\hline Singing folk songs & 234 & 5.4 & 3089 & 71.6 & 989 & 22.9 & & \\
\hline Listening to folk music & 2567 & 59.5 & 1513 & 35.1 & 232 & 5.4 & & \\
\hline Playing folk instruments & 2308 & 53.5 & 1806 & 41.9 & 198 & 4.6 & & \\
\hline $\begin{array}{l}\text { Attending events where } \\
\text { folk music is played }\end{array}$ & 1424 & 33 & 2789 & 64.7 & 99 & 2.3 & & \\
\hline $\begin{array}{l}\text { Active involvement of parents in } \\
\text { groups producing folk music } \\
\text { (choir, folk band, folk dance group) }\end{array}$ & 4155 & 96.3 & 112 & 2.6 & 45 & 1 & 4312 & 100 \\
\hline Purchase of CDs with folk music & 1997 & 46.3 & 1892 & 43.9 & 423 & 9.8 & & \\
\hline $\begin{array}{l}\text { Purchase of sheet music } \\
\text { with folk songs (songbooks) }\end{array}$ & 1312 & 30.4 & 2236 & 51.9 & 764 & 17.7 & & \\
\hline
\end{tabular}


Table 5. Frequency of children engaging in music activities with their families.

\begin{tabular}{|c|c|c|c|c|c|c|c|c|}
\hline \multirow[b]{2}{*}{ Activities } & \multicolumn{2}{|c|}{ Never } & \multicolumn{2}{|c|}{ Rarely } & \multicolumn{2}{|c|}{ Frequently } & \multicolumn{2}{|c|}{ Total } \\
\hline & $\mathrm{f}$ & $\mathrm{f} \%$ & $\mathrm{f}$ & $\mathrm{f} \%$ & $\mathrm{f}$ & $\mathrm{f} \%$ & $\mathrm{f}$ & $\mathrm{f} \%$ \\
\hline Singing folk songs & 122 & 2.8 & 2698 & 62.6 & 1492 & 34.6 & & \\
\hline Listening to folk music & 2433 & 56.4 & 1691 & 39.2 & 188 & 4.4 & 4312 & 100 \\
\hline Playing folk instruments & 2750 & 63.8 & 1517 & 35.2 & 45 & 1.0 & & \\
\hline
\end{tabular}

Although the results showed that more than half of the parents do not sing folk songs, play folk instruments, or listen to folk music at home, the majority of parents (91.9\%) do attribute great importance to folk music. This is evident from the following answers: folk music is a memory of the past; it is part of our lives; it is our cultural heritage which cheers us up; it is about respect for tradition; it is part of Slovenian tradition which needs to be preserved; it is the basis of our past, present, and future.

\section{Conclusions}

Our survey results suggest that musical activities related to folk music are not sufficiently incorporated into education process or home environment. Children should learn more folk songs in the kindergarten, and sing them more frequently. Preschool teachers should be familiar with the criteria for the selection of appropriate folk songs, taking into consideration the level of children's musical skills. Furthermore, they should pay more attention to listening to folk music and playing folk instruments. The world of children's musical instruments and sounders is extremely varied. A child can see a toy in nearly any object and can easily turn it into a musical instrument, which they can listen to or use to produce different sounds, thus encouraging their own creativity. When discussing folk music tradition, the teacher must aim at all musical activities being equally represented.

In the past, the family and the life within a community were two paramount factors in preserving music as cultural heritage. Nowadays, however, our lifestyles have been changing continuously while our taste in music has been increasingly influenced by the media, kindergarten, school, and cultural institutions. For this reason, the family which represents a key element in preserving folk traditions should take a more active role in transferring knowledge to younger generations. Parents should motivate children more than they do and promote their interest in and love of folk music at home through their own active engagement. Parents that are passive towards producing and listening to folk music will have a direct impact on the attitude their children will have towards such activities.

What can be done to raise the awareness of one's cultural heritage and children's interest in it?

Plevnik (Plevnik, 2010) believes that in Slovenia, we need to raise the aware- 
ness of the role cultural education plays within the education system, improve the level of cultural literacy, and establish a proper connection between education and culture. We need to realise that key success factors include preschool teachers with a vision that incorporates the integration of folk music into the education process and parents who promote love of and a proper attitude towards cultural heritage in their children through their own knowledge and engagement from the child's earliest years on.

\section{Conflicts of Interest}

The authors declare no conflicts of interest regarding the publication of this paper.

\section{References}

Borota, B. (2010). Raziskava o pevskem repertoarju v vrtcu, v oddelkih otrok prvegastarostnega obdobja [Survey on Song Repertoire in Kindergarten, among Children in the First Age Group]. Glasba v šoli in vrtcu, 15, 6-14.

Cvetko, I. (1991). Med godci in glasbili na Slovenskem [Among Folk Musicians and Instruments in Slovenia]. Ljubljana: Sekcija za glasbeno narodopisje.

Fu, L. (2010). Folk Music Plays a Crucial Role in Children's Development: Research on How to Effectively Integrate Folk Music into Kindergarten Music Education, ISME. http://citation.allacademic.com/meta/p406168_index.html

Kumer, Z. (1987). Pesmi in šege moje dežele [Songs and Customs of My Homeland]. Ljubljana: Državna založba Slovenije.

Kumer, Z. (2002). Slovenska ljudska pesem [Slovenian Folk Song]. Ljubljana: Slovenska Matica.

Omerzel Terlep, M. (1984). Slovenska ljudska glasba [Slovenian Folk Music]. Revija glasbene mladine Slovenije, 8,14 .

Plevnik, P. (2010). Kulturno-umetnostna vzgoja po šolah v Evropi [Arts and Cultural Education at School in Europe]. Ljubljana: Ministrstvo za šolstvo in šport.

Zalar, K. (2015). Children's Folk Music in Primary School. In B. Sicherl-Kafol (Ed.), Contemporary Approaches to Music Teaching and Learning. Saarbrücken: Lambert.

Žgavec, M. (2004). Slovenska ljudska glasba [Slovenian Folk Music]. Glasba $v$ šoli in vrtcu, 9, 3-4. 